\title{
Winogradskyella arenosi sp. nov., a member of the family Flavobacteriaceae isolated from marine sediments from the Sea of Japan
}

Correspondence Lyudmila A. Romanenko Iro@piboc.dvo.ru

\author{
Lyudmila A. Romanenko, ${ }^{1}$ Naoto Tanaka, $^{2}$ Galina M. Frolova ${ }^{1}$ \\ and Valery $\mathrm{V}$. Mikhailov ${ }^{1}$
}

\author{
${ }^{1}$ Pacific Institute of Bioorganic Chemistry, Far-Eastern Branch, Russian Academy of Sciences, \\ Prospect 100 Let Vladivostoku 159, 690022 Vladivostok, Russia \\ ${ }^{2}$ NODAI Culture Collection Center, Tokyo University of Agriculture, 1-1-1 Sakuragaoka, \\ Setagaya-ku, Tokyo 156-8502, Japan
}

\begin{abstract}
An aerobic, Gram-negative, yellow-pigmented, gliding bacterial strain, designated $\mathrm{R}^{\mathrm{T}} \mathrm{O}^{\top}$, was isolated from a marine sediment sample obtained from the Sea of Japan and was characterized by using a polyphasic approach. $16 \mathrm{~S}$ rRNA gene sequence analysis showed that strain $\mathrm{R}^{\top} \mathrm{T}^{\top}$ belonged to the genus Winogradskyella, sharing $<97 \%$ sequence similarity with the type strains of recognized Winogradskyella species. The main fatty acids of strain $R 60^{\top}$ were iso- $\mathrm{C}_{15: 0}$ 3$\mathrm{OH}$, iso- $\mathrm{C}_{16: 0} 3-\mathrm{OH}$, iso- $\mathrm{C}_{17: 0} 3-\mathrm{OH}$, anteiso- $\mathrm{C}_{17: 0} 3-\mathrm{OH}$ and iso- $\mathrm{C}_{15: 0}$, consistent with its assignment to the genus Winogradskyella. On the basis of phenotypic distinctiveness and phylogenetic divergence, strain $\mathrm{R}^{\top} \mathrm{O}^{\top}$ is considered to represent a novel species of the genus Winogradskyella, for which the name Winogradskyella arenosi sp. nov. is proposed. The type

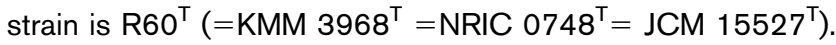

The genus Winogradskyella was proposed by Nedashkovskaya et al. (2005) to accommodate bacteria recovered from brown and green algae from the Peter the Great Bay of the Sea of Japan, with the description of three species: Winogradskyella thalassocola, Winogradskyella epiphytica and Winogradskyella eximia. Subsequently, Lau et al. (2005) described Winogradskyella poriferorum to accommodate a strain isolated from a sponge collected from the Bahamas. Here, we report the characterization of a Gramnegative, aerobic, yellow-pigmented gliding bacterial strain, designated $\mathrm{R} 60^{\mathrm{T}}$, isolated from a marine sediment sample collected from the Peter the Great Bay of the Sea of Japan. Phylogenetic analysis based on 16S rRNA gene sequence data demonstrated that strain $\mathrm{R} 60^{\mathrm{T}}$ belongs to the genus Winogradskyella and may represent a novel species of this genus. Differential phenotypic properties along with phylogenetic distinctiveness supported the proposal that strain $\mathrm{R} 60^{\mathrm{T}}$ represents a novel species of the genus Winogradskyella.

Strain $\mathrm{R} 60^{\mathrm{T}}$ was recovered from a marine sediment sample collected from Peter the Great Bay of the Sea of Japan,

The GenBank/EMBL/DDBJ accession number for the 16S rRNA gene sequence of strain $R 60^{\top}$ is $A B 438962$.

A maximum-parsimony phylogenetic tree based on 16S rRNA gene sequences showing the position of strain $\mathrm{R} 6 \mathrm{O}^{\top}$ among recognized Winogradskyella species and related taxa is available with the online version of this paper.
Russia, in June 2002. It grew aerobically on marine agar 2216 (MA) or marine broth 2216 (MB; both from Difco) at 25-28 ${ }^{\circ} \mathrm{C}$, and the strain was stored at $-80{ }^{\circ} \mathrm{C}$ in $\mathrm{MB}$ supplemented with $30 \%(\mathrm{v} / \mathrm{v})$ glycerol.

Gliding motility was observed according to the method described by Bowman (2000) by using oil-immersion phase-contrast microscopy (AX70; Olympus). The presence of flexirubin pigments was investigated as described by Fautz \& Reichenbach (1980). The Gram reaction, oxidase and catalase reactions and hydrolysis of casein, gelatin, starch, alginate, cellulose (CM-cellulose and filter paper), chitin and Tweens 20, 40 and 80 were tested according to the standard methods described by Smibert \& Krieg (1994). Formation of $\mathrm{H}_{2} \mathrm{~S}$ from thiosulfate was tested by using a lead acetate paper strip. Acid production from carbohydrates was examined by using the oxidation/ fermentation medium of Leifson (1963) for marine bacteria, with carbohydrates tested at a concentration of $1 \%(\mathrm{w} / \mathrm{v})$. Growth at different temperatures, $\mathrm{pH}$ and salinities was studied as described previously (Romanenko et al., 2004, 2007). Biochemical tests were carried out by using API 20NE, API ID32 GN, API $50 \mathrm{CH}$ and API ZYM test kits (bioMérieux) as described by the manufacturer, and results were read daily over 5 days incubation at $25{ }^{\circ} \mathrm{C}$. For fatty acid analysis, strain $\mathrm{R} 60^{\mathrm{T}}$ was cultivated on MA at $25{ }^{\circ} \mathrm{C}$ for 3 days, and lipids were extracted by using the chloroform-methanol extraction method of Bligh \& Dyer (1959). Fatty acid methyl esters were obtained by using 


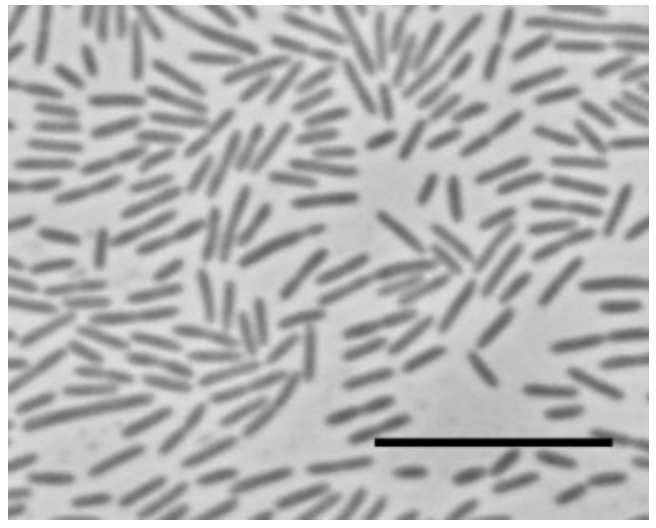

Fig. 1. Photomicrograph showing cells of strain $R 60^{\top}$ observed by oil-immersion phase-contrast microscopy. Bar, $10 \mu \mathrm{m}$.

Table 1. Differential phenotypic characteristics between strain $\mathrm{R}^{\mathrm{T}} \mathrm{T}^{\top}$ and recognized Winogradskyella species

Taxa: 1, strain $\mathrm{R} 60^{\mathrm{T}} ; 2, W$. poriferorum (data from Lau et al., 2005); 3, W. epiphytica; 4, W. eximia; 5, W. thalassocola (data for taxa 3-5 from Nedashkovskaya et al., 2005). All are positive for gliding motility, oxidase, catalase and alkaline phosphatase activities, and gelatin and Tween 40 hydrolysis; all are negative for flexirubin pigments, indole production, nitrate reduction, $\beta$-galactosidase and urease production, cellulose and chitin hydrolysis, and utilization of L-arabinose, sucrose, D-mannitol, inositol, D-lactose, D-sorbitol and citrate. + , Positive; - , negative; ND, not determined.

\begin{tabular}{|c|c|c|c|c|c|}
\hline Characteristic & 1 & 2 & 3 & 4 & 5 \\
\hline $\mathrm{H}_{2} \mathrm{~S}$ production & + & - & - & - & - \\
\hline \multicolumn{6}{|l|}{ Growth at/in: } \\
\hline $4{ }^{\circ} \mathrm{C}$ & + & - & + & + & + \\
\hline $35{ }^{\circ} \mathrm{C}$ & + & + & + & - & - \\
\hline $37^{\circ} \mathrm{C}$ & - & + & + & - & - \\
\hline $44^{\circ} \mathrm{C}$ & - & + & - & - & - \\
\hline $8 \% \mathrm{NaCl}$ & + & - & + & - & + \\
\hline \multicolumn{6}{|c|}{ Acid production from: } \\
\hline D-Glucose & + & $\mathrm{ND}$ & - & + & + \\
\hline Maltose & + & ND & - & + & + \\
\hline Sucrose & - & $\mathrm{ND}$ & - & + & - \\
\hline Cellobiose & - & $\mathrm{ND}$ & - & - & + \\
\hline D-Mannitol & + & $\mathrm{ND}$ & - & + & - \\
\hline \multicolumn{6}{|l|}{ Hydrolysis of: } \\
\hline Casein & - & - & - & + & - \\
\hline DNA & - & + & + & - & - \\
\hline Tween 20 & + & + & + & + & - \\
\hline Tween 80 & + & + & + & - & - \\
\hline Starch & + & - & - & + & - \\
\hline Agar & - & - & + & + & + \\
\hline \multicolumn{6}{|l|}{ Utilization of: } \\
\hline D-Glucose & - & - & - & + & + \\
\hline Cellobiose & - & - & ND & - & ND \\
\hline D-Mannose & - & - & - & + & + \\
\hline Maltose & - & - & ND & + & ND \\
\hline
\end{tabular}

Table 2. Cellular fatty acid composition (\%) of strain $\mathrm{R}^{\circ} \mathrm{O}^{\top}$ and recognized Winogradskyella species

Taxa: 1, strain $\mathrm{R}^{\mathrm{T}}{ }^{\mathrm{T}} ; 2$, W. poriferorum (data from Lau et al., 2005); 3, W. epiphytica; 4, W. eximia; 5, W. thalassocola (data for taxa 3-5 from Nedashkovskaya et al., 2005). Results are percentages of total fatty acids; - , not found.

\begin{tabular}{|c|c|c|c|c|c|}
\hline Fatty acid & 1 & 2 & 3 & 4 & 5 \\
\hline iso- $\mathrm{C}_{13: 0}$ & - & $2.6 \pm 0.1^{*}$ & - & - & - \\
\hline iso- $\mathrm{C}_{14: 0}$ & - & $1.2 \pm 0.1$ & 4.5 & 1.4 & 2.6 \\
\hline iso- $\mathrm{C}_{14: 0} 3-\mathrm{OH}$ & - & $0.5 \pm 0.1$ & 1.6 & - & 0.9 \\
\hline iso- $\mathrm{C}_{14: 1}$ & - & $2.0 \pm 0.3$ & 1.4 & - & - \\
\hline $\mathrm{C}_{15: 0}$ & 1.7 & - & 1.2 & 6.7 & 7.9 \\
\hline anteiso- $\mathrm{C}_{15: 0}$ & 5.6 & - & 15.9 & 7.0 & 4.9 \\
\hline iso- $\mathrm{C}_{15: 0}$ & 9.3 & $12.6 \pm 1.1$ & 6.7 & 25.6 & 8.7 \\
\hline anteiso- $\mathrm{C}_{15: 0} 3-\mathrm{OH}$ & 3.4 & - & - & - & - \\
\hline iso- $\mathrm{C}_{15: 0} 3-\mathrm{OH}$ & 17.0 & $9.8 \pm 1.0$ & 2.9 & 2.6 & 11.9 \\
\hline $\mathrm{C}_{15: 0} 2-\mathrm{OH}$ & - & $3.1 \pm 0.5$ & 3.3 & 1.0 & 1.8 \\
\hline $\mathrm{C}_{15: 0} 3-\mathrm{OH}$ & 0.9 & $2.4 \pm 0.7$ & - & - & 2.5 \\
\hline $\mathrm{C}_{15: 1} \omega 6$ & 1.1 & - & - & - & 6.5 \\
\hline anteiso- $\mathrm{C}_{15: 1}$ & 0.9 & $1.5 \pm 0.2$ & 6.3 & 1.4 & 1.6 \\
\hline iso- $\mathrm{C}_{15: 1}$ & 5.2 & $20.9 \pm 0.6$ & 8.1 & 10.4 & 11.4 \\
\hline anteiso- $\mathrm{C}_{15: 0} 2-\mathrm{OH}$ & 4.9 & - & - & - & - \\
\hline iso- $\mathrm{C}_{15: 0} 2-\mathrm{OH}$ & 3.6 & - & - & - & - \\
\hline $\begin{array}{l}\text { iso- } \mathrm{C}_{15: 0} 2-\mathrm{OH} / \\
\mathrm{C}_{16: 1} \omega 7\end{array}$ & - & $9.8 \pm 0.8$ & 5.1 & 6.1 & 4.2 \\
\hline$C_{16: 0}$ & 1.0 & - & - & - & - \\
\hline$C_{16: 0}$ 10-methyl & - & - & - & 6.3 & - \\
\hline $\mathrm{C}_{16: 0} 3-\mathrm{OH}$ & - & $1.3 \pm 0.1$ & - & - & 1.0 \\
\hline iso- $\mathrm{C}_{16: 0}$ & 0.6 & $0.5 \pm 0.2$ & 3.7 & 5.7 & 0.8 \\
\hline iso- $\mathrm{C}_{16: 0} 3-\mathrm{OH}$ & 13.8 & $11.4 \pm 0.1$ & 17.1 & 32 & 18.1 \\
\hline anteiso- $\mathrm{C}_{16: 0} 3-\mathrm{OH}$ & 1.2 & - & - & - & - \\
\hline iso- $\mathrm{C}_{16: 1}$ & - & $0.8 \pm 0.3$ & 3.5 & 4.7 & 2.7 \\
\hline $\mathrm{C}_{17: 0} 2-\mathrm{OH}$ & - & 0.3 & 5.2 & 1.0 & 0.8 \\
\hline $\mathrm{C}_{17: 0}$ cyclo & - & - & - & 2.4 & - \\
\hline iso- $\mathrm{C}_{17: 0} 3-\mathrm{OH}$ & 17.1 & $10.2 \pm 0.7$ & 7.3 & 6.7 & 5.4 \\
\hline anteiso- $\mathrm{C}_{17: 0} 3-\mathrm{OH}$ & 8.5 & - & - & - & - \\
\hline anteiso- $\mathrm{C}_{17: 1}$ & - & - & - & 2.3 & - \\
\hline iso- $\mathrm{C}_{17: 1} \omega 9$ & - & - & 1.1 & - & 0.6 \\
\hline$C_{17: 1} \omega 6$ & 1.0 & 0.2 & 1.9 & - & 0.9 \\
\hline $\mathrm{C}_{18: 1}$ & 2.1 & - & - & - & - \\
\hline Unknown & 1.0 & $3.9 \pm 0.6$ & 3.7 & 5.6 & 4.8 \\
\hline
\end{tabular}

${ }^{\star}$ Mean \pm SD.

acid methanolysis as described by Rowe et al. (2000). The resultant fatty acid methyl esters were extracted by hexane and were analysed by using a GLC-MS Hewlett Packard model 6890 gas chromatograph equipped with an HP 5 MS $5 \%$ phenyl methyl siloxane capillary column $(30 \mathrm{~m} \times 250 \mu \mathrm{m} \times 0.25 \mu \mathrm{m})$, connected to a Hewlett Packard model 5973 mass spectrometer. The 16S rRNA gene sequence of strain $\mathrm{R}^{\mathrm{T}} \mathrm{T}^{\mathrm{T}}$ (1430 nt) was determined as described by Shida et al. (1997). The sequence obtained was compared with 16S rRNA gene sequences retrieved from GenBank databases by using the FASTA program (Pearson \& Lipman, 1988). Phylogenetic analysis of $16 \mathrm{~S}$ 


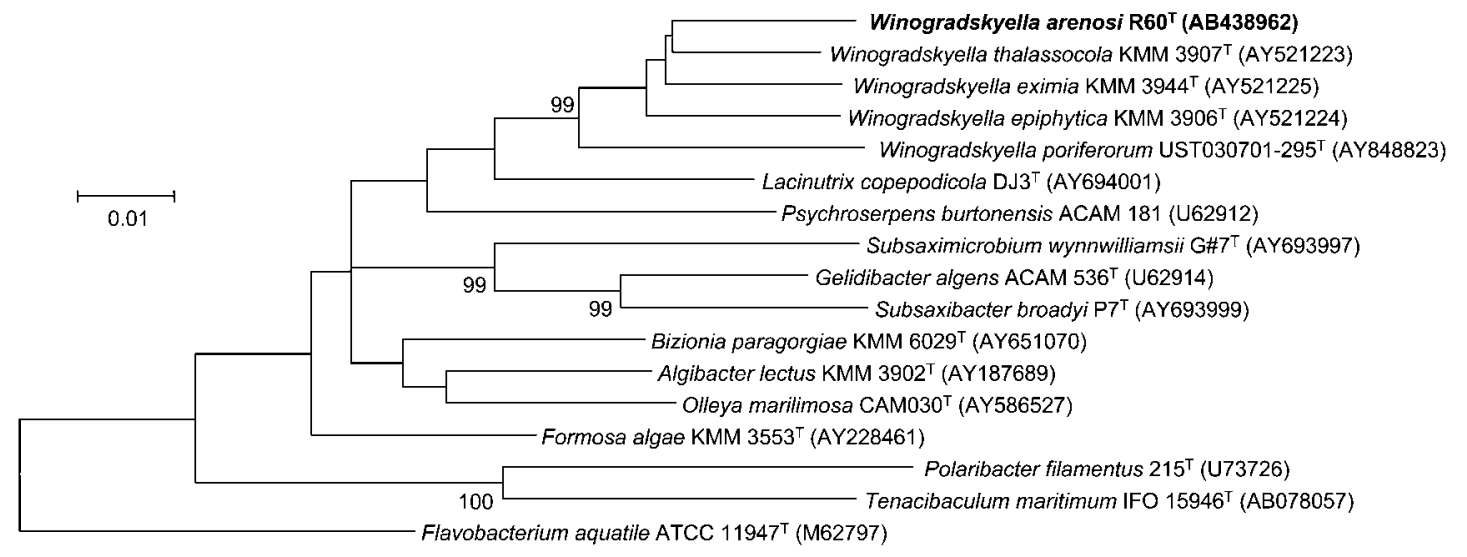

Fig. 2. Neighbour-joining phylogenetic tree based on $16 \mathrm{~S}$ rRNA gene sequences available from GenBank (accession numbers in parentheses), showing the position of strain $\mathrm{R} 60^{\top}\left(=\mathrm{KMM} 3968^{\top}\right)$ among the type strains of recognized Winogradskyella species and related taxa. Phylogenetic analysis was performed by using the software package MEGA4 (Tamura et al., 2007) after multiple alignment of the data by CLUSTAL x (version 1.83; Thompson et al., 1997). Bootstrap values based on 1000 replications are given as percentages at branch points. Bar, 0.01 substitutions per nucleotide position.

rRNA gene sequences was performed by using the software package MEGA4 (Tamura et al., 2007) after multiple alignment of the data by CLUSTAL $\mathrm{x}$ (version 1.83; Thompson et al., 1997). Phylogenetic trees were constructed by using the neighbour-joining and maximumparsimony methods and distances were calculated according to the Kimura two-parameter model. The robustness of the trees was estimated by bootstrap analysis of 1000 replicates.

Phenotypically, strain $\mathrm{R} 60^{\mathrm{T}}$ matched the description of the genus Winogradskyella, being Gram-negative, aerobic, oxidase- and catalase-positive, motile by means of gliding, yellow-pigmented and halophilic. The morphological, physiological and biochemical properties of strain $\mathrm{R} 60^{\mathrm{T}}$ are shown in Fig. 1, Table 1 and in the species description below. The fatty acid profile of strain $\mathrm{R} 60^{\mathrm{T}}$ was characterized by the abundance of branched 3-hydroxy components, including iso- $\mathrm{C}_{15: 0} 3-\mathrm{OH}$, iso- $\mathrm{C}_{16: 0} 3-\mathrm{OH}$, iso- $\mathrm{C}_{17: 0} 3-\mathrm{OH}$ and anteiso- $\mathrm{C}_{17: 0} 3-\mathrm{OH}(47.9 \%$ of the total) as the predominant fatty acids (Table 2). The presence of iso- $\mathrm{C}_{15: 0}(9.3 \%)$, iso- $\mathrm{C}_{15: 0} 3-\mathrm{OH}(17.0 \%)$, iso- $\mathrm{C}_{16: 0} 3-\mathrm{OH}(13.8 \%)$, iso- $\mathrm{C}_{17: 0} 3-\mathrm{OH}(17.1 \%)$ and iso- $\mathrm{C}_{15: 1}(5.2 \%)$ is in accordance with data reported previously for recognized Winogradskyella species (Lau et al., 2005; Nedashkovskaya et al., 2005), although some quantitative and qualitative differences were observed (Table 2). Unlike recognized Winogradskyella species, strain $\mathrm{R} 60^{\mathrm{T}}$ contained a significant amount of anteiso$\mathrm{C}_{17: 0} 3-\mathrm{OH}(8.5 \%)$, smaller amounts of anteiso- $\mathrm{C}_{15: 0} 2-$ $\mathrm{OH}(4.9 \%)$, anteiso- $\mathrm{C}_{15: 0} 3-\mathrm{OH}(3.4 \%), \mathrm{C}_{18: 1}(2.1 \%)$ and anteiso- $\mathrm{C}_{16: 0} 3-\mathrm{OH}(1.2 \%)$ and did not contain iso$\mathrm{C}_{14: 0}$, iso- $\mathrm{C}_{16: 1}$ or $\mathrm{C}_{15: 0} 2-\mathrm{OH}$.

Phylogenetic analysis based on 16S rRNA gene sequencing showed that strain $\mathrm{R} 60^{\mathrm{T}}$ was affiliated to the genus
Winogradskyella, and formed an independent lineage in the neighbour-joining phylogenetic tree (Fig. 2). The same relationship was also evident in the $16 \mathrm{~S}$ rRNA gene sequence dendrogram generated with the maximumparsimony algorithm (Supplementary Fig. S1, available in IJSEM Online). Levels of $16 \mathrm{~S}$ rRNA gene sequence similarity between strain $\mathrm{R} 60^{\mathrm{T}}$ and the type strains of recognized Winogradskyella species (94.6-96.6\%) were below the $97.0 \%$ threshold recommended for the discrimination of different bacterial species (Stackebrandt \& Goebel, 1994). Based on data from phylogenetic analysis, strain $\mathrm{R}^{\mathrm{T}}$ could not be assigned to any recognized species and thus represents a novel species of the genus Winogradskyella. The phylogenetic distinctiveness of strain $\mathrm{R} 60^{\mathrm{T}}$ was supported by phenotypic differences in its temperature and salinity ranges for growth, substrate utilization pattern and metabolic properties (Table 1). Based on the combination of phenotypic and biochemical characteristics, as well as phylogenetic position, strain $\mathrm{R}^{\mathrm{T}}$ is considered to represent a novel species of the genus Winogradskyella, for which the name Winogradskyella arenosi sp. nov. is proposed.

\section{Description of Winogradskyella arenosi sp. nov.}

Winogradskyella arenosi (a.re.no'si. L. gen. n. arenosi of a sandy place, dwelling in marine sand).

An aerobic, Gram-negative, oxidase- and catalase-positive, yellow-pigmented, gliding, rod-shaped bacterium (0.2$0.3 \mu \mathrm{m}$ in diameter and $1.7-2.5 \mu \mathrm{m}$ in length) (Fig. 1). Cells occur singly or in pairs. On MA, yellow-pigmented, shiny, smooth, slimy colonies, $3-5 \mathrm{~mm}$ in diameter, are formed. Flexirubin and diffusible pigments are not produced. Sodium ions are required for growth. Growth occurs in the presence of $0.5-9.0 \% \mathrm{NaCl}$. Growth 
temperature range is $4-35{ }^{\circ} \mathrm{C}$, with optimum growth at $25-$ $28{ }^{\circ} \mathrm{C}$. No growth occurs at $37{ }^{\circ} \mathrm{C}$. Casein, chitin, cellulose (CM-cellulose and filter paper), agar and DNA are not hydrolysed. Positive for starch hydrolysis. Gelatin is hydrolysed slowly over 3-5 days in both routine and API 20NE tests. Tweens 20, 40 and 80 are hydrolysed. $\mathrm{H}_{2} \mathrm{~S}$ production is positive. Acid is produced from D-glucose, maltose, mannose and D-mannitol, but not from sucrose, D-cellobiose, arabinose, rhamnose, galactose or xylose. In API 20NE tests, positive for hydrolysis of aesculin, but negative for reduction of nitrate, production of indole, production of acid from glucose and assimilation of arginine dihydrolase, urease, $\beta$-galactosidase, arabinose, mannose, mannitol, $N$-acetylglucosamine, maltose, gluconate, caprate, adipate, malate, citrate and phenylacetate. In API $50 \mathrm{CH}$ tests, positive for utilization of aesculin, but negative for utilization of glycerol, erythritol, D-arabinose, L-arabinose, D-ribose, D-xylose, L-xylose, D-adonitol, methyl $\beta$-D-xylopyranoside, D-galactose, D-glucose, Dfructose, D-mannose, L-sorbose, L-rhamnose, dulcitol, inositol, D-mannitol, D-sorbitol, methyl $\alpha$-D-mannopyranoside, methyl $\alpha$-D-glucopyranoside, $N$-acetylglucosamine, amygdalin, arbutin, salicin, cellobiose, maltose, Dlactose, melibiose, sucrose, trehalose, inulin, melezitose, raffinose, starch, glycogen, xylitol, gentiobiose, turanose, D-lyxose, D-tagatose, D-fucose, L-fucose, L-arabitol, Darabitol, gluconate, potassium 2-ketogluconate and potassium 5-ketogluconate. In API ZYM tests, positive for alkaline phosphatase, esterase (C4), esterase lipase (C8), leucine arylamidase, valine arylamidase, cystine arylamidase, acid phosphatase and naphthol-AS-BI-phosphohydrolase, weakly positive for $\alpha$-glucosidase, but negative for lipase (C14), trypsin, $\alpha$-chymotrypsin, $\alpha$-galactosidase, $\beta$-galactosidase, $\beta$-glucuronidase, $\beta$-glucosidase, $N$-acetyl$\beta$-glucosaminidase, $\alpha$-mannosidase and $\alpha$-fucosidase. Predominant fatty acids are iso- $\mathrm{C}_{15: 0} 3-\mathrm{OH}$, iso- $\mathrm{C}_{16: 0}$ $3-\mathrm{OH}$, anteiso- $\mathrm{C}_{17: 0} 3-\mathrm{OH}$, iso- $\mathrm{C}_{17: 0} 3-\mathrm{OH}$ and iso$\mathrm{C}_{15: 0}$; smaller amounts of anteiso- $\mathrm{C}_{15: 0}$, iso- $\mathrm{C}_{15: 1}$, anteiso- $\mathrm{C}_{15: 0} 2-\mathrm{OH}$, iso- $\mathrm{C}_{15: 0} 2-\mathrm{OH}$ and anteiso- $\mathrm{C}_{15: 0}$ $3-\mathrm{OH}$ are present; and iso- $\mathrm{C}_{16: 0}$, anteiso- $\mathrm{C}_{16: 0} 3-\mathrm{OH}$, $\mathrm{C}_{16: 0}, \mathrm{C}_{15: 0} \quad 3-\mathrm{OH}, \mathrm{C}_{15: 1} \omega 6$, anteiso- $\mathrm{C}_{15: 1}, \mathrm{C}_{15: 0}$, $\mathrm{C}_{17: 1} \omega 6$ and $\mathrm{C}_{18: 1}$ occur as minor components.

The type strain, $\mathrm{R} 60^{\mathrm{T}}\left(=\mathrm{KMM} 3968^{\mathrm{T}}=\right.$ NRIC $0748^{\mathrm{T}}=\mathrm{JCM}$ $15527^{\mathrm{T}}$ ), was isolated from a marine sediment sample collected from Peter the Great Bay of the Sea of Japan.

\section{Acknowledgements}

This study was supported by a grant from the Russian Foundation for Basic Research (RFBR; 08-04-00099), and by grant 06-III-A-06-183 from the Presidium of the Far-Eastern Branch of the Russian Academy of Sciences.

\section{References}

Bligh, E. G. \& Dyer, W. J. (1959). A rapid method of total lipid extraction and purification. Can J Biochem Physiol 37, 911-917.

Bowman, J. P. (2000). Description of Cellulophaga algicola sp. nov., isolated from the surface of Antarctic algae, and reclassification of Cytophaga uliginosa (ZoBell and Upham 1944) Reichenbach 1989 as Cellulophaga uliginosa comb. nov. Int J Syst Evol Microbiol 50, 18611868.

Fautz, E. \& Reichenbach, H. (1980). A simple test for flexirubin-type pigments. FEMS Microbiol Lett 8, 87-91.

Lau, S. C. K., Tsoi, M. M. Y., Li, X., Plakhotnikova, I., Dobretsov, S., Lau, K. W. K., Wu, M., Wong, P.-K., Pawlik, J. R. \& Qian, P.-Y. (2005). Winogradskyella poriferorum sp. nov., a novel member of the family Flavobacteriaceae isolated from a sponge in the Bahamas. Int J Syst Evol Microbiol 55, 1589-1592.

Leifson, E. (1963). Determination of carbohydrate metabolism of marine bacteria. J Bacteriol 85, 1183-1184.

Nedashkovskaya, O. I., Kim, S. B., Han, S. K., Snauwaert, C., Vancanneyt, M., Swings, J., Kim, K. O., Lysenko, A. M., Rohde, M. \& other authors (2005). Winogradskyella thalassocola gen. nov., sp. nov., Winogradskyella epiphytica sp. nov. and Winogradskyella eximia sp. nov., marine bacteria of the family Flavobacteriaceae. Int J Syst Evol Microbiol 55, 49-55.

Pearson, W. R. \& Lipman, D. J. (1988). Improved tools for biological sequence comparison. Proc Natl Acad Sci U S A 85, 2444-2448.

Romanenko, L. A., Schumann, P., Rohde, M., Mikhailov, V. V. \& Stackebrandt, E. (2004). Reinekea marinisedimentorum gen. nov., sp. nov., a novel gammaproteobacterium from marine coastal sediments. Int J Syst Evol Microbiol 54, 669-673.

Romanenko, L. A., Uchino, M., Frolova, G. M. \& Mikhailov, V. V. (2007). Marixanthomonas ophiurae gen. nov., sp. nov., a novel marine bacterium of the family Flavobacteriaceae isolated from a deep-sea brittle star. Int J Syst Evol Microbiol 57, 457-462.

Rowe, N. J., Tunstall, J., Galbraith, L. \& Wilkinson, S. G. (2000). Lipid composition of [Pseudomonas] echinoides: transfer to the genus Sphingomonas. Microbiology 146, 3007-3012.

Shida, O., Takagi, H., Kadowaki, K., Nakamura, L. K. \& Komagata, K. (1997). Transfer of Bacillus alginolyticus, Bacillus chondroitinus, Bacillus curdlanolyticus, Bacillus glucanolyticus, Bacillus kobensis, and Bacillus thiaminolyticus to the genus Paenibacillus and emended description of the genus Paenibacillus. Int J Syst Bacteriol 47, 289-298.

Smibert, R. M. \& Krieg, N. R. (1994). Phenotypic characterization. In Methods for General and Molecular Bacteriology, pp. 607-654. Edited by P. Gerhardt, R. G. E. Murray, W. A. Wood \& N. R. Krieg. Washington, DC: American Society for Microbiology.

Stackebrandt, E. \& Goebel, B. M. (1994). Taxonomic note: a place for DNA-DNA reassociation and $16 \mathrm{~S}$ rRNA sequence analysis in the present species definition in bacteriology. Int J Syst Bacteriol 44, 846-849.

Tamura, K., Dudley, J., Nei, M. \& Kumar, S. (2007). MEGA4: molecular evolutionary genetics analysis (MEGA) software version 4.0. Mol Biol Evol 24, 1596-1599.

Thompson, J. D., Gibson, T. J., Plewniak, F., Jeanmougin, F. \& Higgins, D. G. (1997). The CLUSTAL_X windows interface: flexible strategies for multiple sequence alignment aided by quality analysis tools. Nucleic Acids Res 25, 4876-4882. 